\title{
Groundwater geochemical evolution under the influence of polymetallic deposit in Czarnów (Western Sudetes, SW Poland)
}

\author{
Agata Mickiewicz $^{1} \cdot$ Henryk Marszałek ${ }^{1}$
}

Received: 26 May 2015 / Accepted: 9 December 2015/Published online: 10 March 2016

(C) The Author(s) 2016. This article is published with open access at Springerlink.com

\begin{abstract}
Water environment in the vicinity of Czarnów (Rudawy Janowickie Mts., Western Sudetes) is characterized by an occurrence of rich variety of trace elements affecting its quality directly. Based on the analyses of chemical composition of waters supported by geochemical modeling using PHREEQC code the significant influence of either natural geological conditions or former and contemporary mining activity has been confirmed. The results of inverse modeling suggest the contribution of carbon dioxide dissolution, pyrite oxidation, carbonates and plagioclases dissolution and ionic exchange between $\mathrm{Ca}^{2+}$ and $\mathrm{Na}^{+}$as major chemical processes influencing water chemistry evolution. The anomalous concentration of arsenic in several locations as a result of probable desorption from iron oxide-hydroxides under the elevated $\mathrm{pH}$ conditions can be observed. The evaluation of changes in waters chemical composition during the past three decades indicates the tendency of their self-purification.
\end{abstract}

Keywords Geochemical modeling - Geochemical evolution · Groundwater · Western Sudetes · Poland

Agata Mickiewicz

agata.mickiewicz@ing.uni.wroc.pl

Henryk Marszałek

henryk.marszalek@ing.uni.wroc.pl

1 Institute of Geological Sciences, University of Wrocław, Pl. Maksa Borna 9, 50-204 Wrocław, Poland

\section{Introduction}

The mining activity in the Rudawy Janowickie Mts. range (Western Sudetes) has reached the medieval times. The very first records of mine workings in the area are dated from the thirteenth century and can be considered as one of the oldest in Europe. The earliest stage of exploitation regarded only gold exploration until the middle of the eighteenth century when the 'Evelinens Glück' mine ('Eveline's Luck' mine) was launched and the workings focused on arsenic and copper ores exploitation. At the beginning of the twentieth century the exploitation in Czarnów was conducted on 12 exploitation levels and the production came up to $1000 \mathrm{t}$ of ore annually (Dziekoński 1972). The operation of the 'Evelinens Glück' mine was finished in 1925 considering its unprofitability. Currently the mine is closed and unavailable for entry. The remainings of its former activity in the form of shafts, adits and mine tailings have still a huge impact on the entire environment and play a significant role in the evolution of water chemistry in the study area. The additional influence on the waters exerts the present exploitation of dolomitic marbles in open-pit mine in Rędziny.

Rudawy Janowickie Mts. has been the point of interest for a few last decades considering its interesting geological structure and mining history. The scientific investigations in the Czarnów area regarding the aspects of geology, mineralogy and tectonics were conducted by many Polish scientists (i.a. Zimnoch 1985; Cymerman 1996; Mazur and Aleksandrowski 2001; Mazur 2003; Kozdrój 2003; Mochnacka et al. 2009; Mikulski 2010). The latest description of mining history and heritage in Rudawy Janowickie can be found in several articles in the monograph 'Mining history-element of European culture heritage (Zagozdzon and Madziarz 2009). Also a few papers 
describing the interactions between water and ore mineralization in Rudawy Janowickie has been published (Balcerzak et al. 1992; Marszalek and Wasik 2001; Konieczyńska 2006). So far the subject of geochemical evolution of waters in Czarnów area has not been commented in the literature.

The aim of the paper is identification of main factors affecting the chemical composition of waters in the area of former arsenic and copper exploitation in Rudawy Janowickie Mts. and recognition of their geochemical evolution based on geochemical modeling using PHREEQC code.

\section{Geological and hydrogeological background}

Geologically the study area is a part of Rudawy Janowickie metamorphic complex located in Western Sudetes (northern part of the Bohemian Massif). The unit is composed mostly of crystalline rocks represented the eastern shield of Variscan granitoid intrusion covered partly with Intrasudetic Basin sediments. Predominant rocks in the area are metamorphic schists, amphibolites, gneisses and dolomitic marbles (Fig. 1). The origin of polymetallic ore is associated with Variscan hydrothermal activity of granite intrusion as well as early Paleozoic magmatic and volcanic activity in Rudawy Janowickie (Mikulski 2010). The mineralization, mainly arsenopyrite (FeAsS), is present in a form of veins and lenses between silicate and carbonate rocks. The other minerals including pyrrhotite $(\mathrm{FeS})$, pyrite $\left(\mathrm{FeS}_{2}\right)$, marcasite $\left(\mathrm{FeS}_{2}\right)$, chalcopyrite $\left(\mathrm{CuFeS}_{2}\right)$, sphalerite $(\mathrm{ZnS})$, galena $(\mathrm{PbS})$ and bornite $\left(\mathrm{Cu}_{5} \mathrm{FeS}_{4}\right)$ are also present.

The hydrogeological conditions in the Rudawy Janowickie are similar to those in other crystalline massifs of the Sudetes (Marszałek 1996; Staśko 2010). Groundwater occurs in three depth zones: within weathering cover with upper part of fractured crystalline rocks, in deeper fractured rocks and the deep tectonic faults. These zones are often connected; however they can also form the independent and isolated hydrodynamic systems. The research area is entirely drained by small mountainous streams (Fig. 1) starting in springs and flowing through the abandoned mining area as well as through the active dolomite mine. The surface waters are exposed to the contamination with trace elements all the way from springs to the stream outlet.

The presence of carbonate rocks in the complex of metamorphic series creates a specific type of alkaline groundwater environment with $\mathrm{pH}$ above 8 , clearly different from mainly acidic groundwater occurring in other parts of the crystalline massif of the Western Sudetes.

\section{Methods}

The geochemical characteristics of groundwater within the study area was carried out based on chemical analyses of water samples collected in January 2013 at 10 sampling locations (Fig. 1). The water was sampled from the local springs, household dug wells and streams. Each of the water samples has been preserved in dark HDPE bottles after previous filtration using $0.45 \mu \mathrm{m}$ membranes. The samples intended for the analyses of cations were additionally acidified with nitric acid. Eight basic ions $\left(\mathrm{HCO}_{3}{ }^{-}\right.$, $\left.\mathrm{SO}_{4}{ }^{2-}, \mathrm{Cl}^{-}, \mathrm{NO}_{3}{ }^{-}, \mathrm{Ca}^{2+}, \mathrm{Mg}^{2+}, \mathrm{Na}^{+}, \mathrm{K}^{+}\right)$were determined using HPLC technique and 7 trace elements (As, $\mathrm{Cu}$, $\mathrm{Fe}, \mathrm{Mn}, \mathrm{Ni}, \mathrm{Pb}, \mathrm{Zn}$ ) using ICP-MS technique. In March 2013 additional analyses of basic chemical composition of water were carried out in five sampling locations to extent the recognition of water chemistry. Also the repetition of basic chemical analyses in five sampling locations was performed to exclude analyses errors.

Measurements of basic physico-chemical parameters of water such as temperature, $\mathrm{pH}$, electrolytic conductivity (EC) and redox potential (Eh) were carried out on-site using calibrated portable WTW 340 multiparametric meter with precision of measurements: $0.01 \mu \mathrm{S} / \mathrm{cm}$ for EC and 0.01 for $\mathrm{pH}$. Inverse geochemical modeling with PHREEQC version 3 was used to identify water-rock interaction processes controlling the geochemical evolution of groundwater. The geochemical model was based on the calculation of the distribution of species and the values of saturation index (SI) for selected minerals.

\section{Results and discussion}

The groundwater in the Czarnów area is characterized by low TDS (total dissolved solids) rarely exceeding $100 \mathrm{mg} /$ L. The spatial distribution of total mineralization reveals the tendency to increase with the distance from the springs. The highest values of mineralization are recorded in the streams of the rural areas due to local pollution from agricultural holdings. The other factor affecting the increment of water mineralization is the presence of mine tailings and dolomite mine. The preceding tendency is confirmed by the measurement of electrolytic conductivity of water ranging from $59 \mu \mathrm{S} / \mathrm{cm}$ in springs to $295 \mu \mathrm{S} / \mathrm{cm}$ in the stream water. The highest value of EC measured in groundwater was $378 \mu \mathrm{S} / \mathrm{cm}$ (Table 1).

Based on the measured $\mathrm{pH}$ values the waters of the study area can be classified as acidic, slightly acidic and slightly alkaline. The $\mathrm{pH}$ ranges from 4.2 to 8.2. The groundwater has also wide ranges of hardness fluctuating from 0.15 to $2.05 \mathrm{meq} / \mathrm{L}$. The highest values of both $\mathrm{pH}$ and hardness 


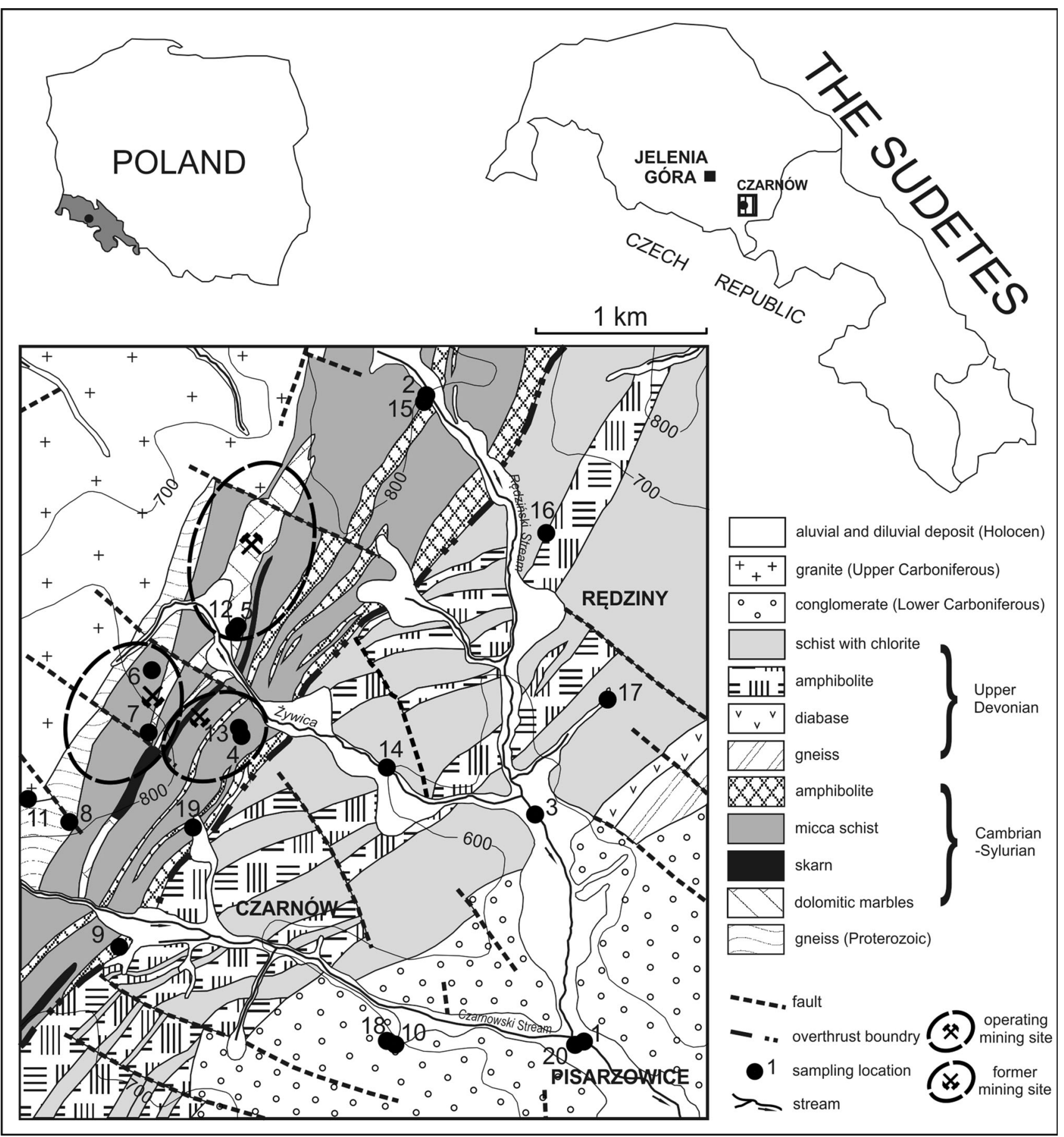

Fig. 1 Location of the sampling waters points on the geological background of the study area

are directly related to weathering of carbonates in the adjacent sites.

Temperature of groundwater, measured at the water outflow, is largely affected by atmospheric conditions. At the time of field measurements in winter period the temperature of water ranged from 2.1 to $5.2{ }^{\circ} \mathrm{C}$. The low values of water temperature indicate the direct influence of atmospheric temperature and respectively the shallow and fast water flow within rock environment.

The predominant ions in groundwater are bicarbonates $\mathrm{HCO}_{3}{ }^{-}$(9.15-122.04 mg/L), sulfides $\mathrm{SO}_{4}{ }^{2-}(8.84-29.20 \mathrm{mg} /$ L), calcium $\mathrm{Ca}^{2+}(1.94-25.63 \mathrm{mg} / \mathrm{L})$ and natrium $\mathrm{Na}^{+}$ (3.66-11.55 mg/L) (Table 1). The higher concentrations of chlorides $\mathrm{Cl}^{-}(1.23-27.32 \mathrm{mg} / \mathrm{L})$ and nitrogen compounds 
Table 1 Chemical composition of surface and groundwater of the study area

\begin{tabular}{llllllllllll}
\hline Water & $\begin{array}{l}\mathrm{SC} \\
\mu \mathrm{S} / \mathrm{cm}\end{array}$ & $\begin{array}{l}\mathrm{pH} \\
-\end{array}$ & $\begin{array}{l}\mathrm{Ca}^{2+} \\
\mathrm{mg} / \mathrm{L}\end{array}$ & $\begin{array}{l}\mathrm{Mg}^{2+} \\
\mathrm{mg} / \mathrm{L}\end{array}$ & $\begin{array}{l}\mathrm{Na}^{+} \\
\mathrm{mg} / \mathrm{L}\end{array}$ & $\begin{array}{l}\mathrm{K}^{+} \\
\mathrm{mg} / \mathrm{L}\end{array}$ & $\begin{array}{l}\mathrm{HCO}_{3}^{-} \\
\mathrm{mg} / \mathrm{L}\end{array}$ & $\begin{array}{l}\mathrm{SO}_{4}^{-} \\
\mathrm{mg} / \mathrm{L}\end{array}$ & $\begin{array}{l}\mathrm{Cl}^{-} \\
\mathrm{mg} / \mathrm{L}\end{array}$ & $\begin{array}{l}\mathrm{NO}_{3}^{-} \\
\mathrm{mg} / \mathrm{L}\end{array}$ & $\begin{array}{l}\mathrm{NO}_{2}^{-} \\
\mathrm{mg} / \mathrm{L}\end{array}$ \\
\hline $\begin{array}{l}\text { Surface } \\
\text { Min }\end{array}$ & & & & & & & & & & & \\
Max & 29.00 & 6.6 & 6.88 & 0.88 & 4.28 & 0.15 & 33.56 & 9.86 & 1.23 & 1.28 & 0.03 \\
Average & 199.19 & 7.4 & 22.64 & 4.42 & 8.77 & 4.41 & 79.78 & 24.17 & 8.41 & 8.70 & 0.08 \\
Ground & & & & & & & & & & & \\
Min & 57.90 & 4.7 & 1.94 & 0.68 & 3.66 & 0.27 & 9.15 & 8.84 & 0.95 & 0.00 & 0.08 \\
Max & 378.00 & 8.2 & 25.63 & 9.92 & 11.55 & 1.89 & 122.04 & 29.20 & 3.90 & 9.35 & 0.12 \\
Average & 140.32 & 6.6 & 14.39 & 2.68 & 6.65 & 0.67 & 46.73 & 18.79 & 1.89 & 2.24 & 0.10 \\
\hline
\end{tabular}

occur in surface water (Table 1) wherein the amount of $\mathrm{NO}_{3}{ }^{-}$ and $\mathrm{NO}_{2}{ }^{-}$ions reach the maximum values of respectively 35.9 and $0.12 \mathrm{mg} / \mathrm{L}$.

Various hydrochemical types of waters (from 3 to 5 main ions) can be distinguished (Fig. 2). Among the basic ions bicarbonates, sulphates, calcium, sodium and magnesium are always prevalent. In hydrochemical terms the surface waters are mainly of the $\mathrm{Ca}-\mathrm{HCO}_{3}-\mathrm{SO}_{4}, \mathrm{Ca}-$ $\mathrm{HCO}_{3}-\mathrm{Cl}$ or $\mathrm{Ca}-\mathrm{Na}-\mathrm{HCO}_{3}-\mathrm{SO}_{4}$ type. In case of groundwater such 4-ions hydrochemical types as $\mathrm{Ca}-\mathrm{Na}-\mathrm{HCO}_{3}-$ $\mathrm{SO}_{4}$ or $\mathrm{Ca}-\mathrm{Na}-\mathrm{SO}_{4}-\mathrm{HCO}_{3}$ predominate.

Predomination of bicarbonates is typical for low-mineralized shallow groundwater and surface water of temperate climatic zone (Macioszczyk and Dobrzynski 2002). The occurrence of sulphate ions in groundwater is an effect of the sulfide minerals presence in adjacent rocks and their transformations in chemical processes. The high concentration of calcium (up to $25.63 \mathrm{mg} / \mathrm{L}$ ) and magnesium (up to $9.92 \mathrm{mg} / \mathrm{L}$ ) cations in groundwater can be related to the weathering of $\mathrm{Mg}$-rich carbonate rocks and the high concentration of sodium cation (up to $11.55 \mathrm{mg} / \mathrm{L}$ ) to the weathering of plagioclases commonly occurred in rocks.

Based on the analyses of the changes in waters chemical composition during the past three decades the visible tendency of water enrichment with bicarbonates in relation to
Fig. 2 Chemical composition of waters in Czarnów region presented on the Piper's diagram

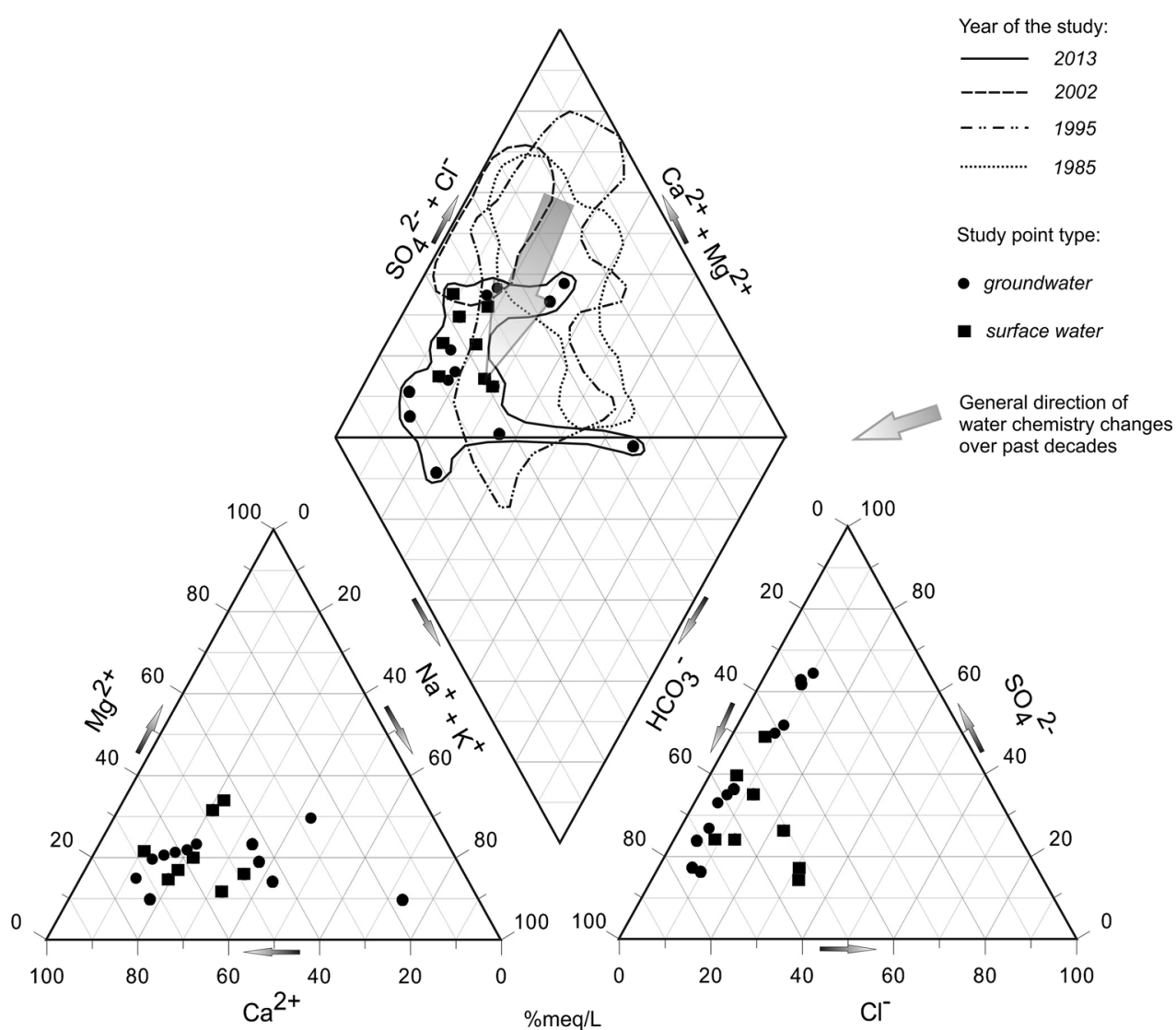


sulphates can be observed (Fig. 2). Such situation is very common in the Sudetes and indicates the slow waters selfpurification and their return to original chemical balance disturbed by environmental disaster in the 1980s as a result of intense acid rains caused by the large-scale burning of fossil fuels on the border of Poland, Germany and Czech Republic. There are no evident differences in total mineralization of waters observed during the past decades. Chemical changes manifest only as variations in proportion between basic ions concentrations.

The chemical analyses of trace elements revealed the presence of anomalous arsenic concentration in waters. Elevated arsenic concentration exceeding the safe limit for drinking water $(10 \mu \mathrm{g} / \mathrm{L}$ according to Polish and WHO regulations) was found in waters of four study sites (Nos. 1, 3, 4 and 5) in the closest vicinity of mine tailings and dolomite mine and also in the surface water of streams. The highest values of arsenic ranged 18.27-158.77 $\mu \mathrm{g} / \mathrm{L}$ (Fig. 3). Out of the analyzed heavy metals the trace amounts of iron, copper, zinc and nickel were also detected (Fig. 3). Due to the very toxic properties of arsenic and its elevated concentrations in water only this element can be a particular health concern for local community.
Except of arsenic, out of the group of seven analyzed trace elements increased concentrations of $\mathrm{Ni}$ were registered in studied water samples (maximum values of $3.11 \mu \mathrm{g} / \mathrm{L}$ for surface water and $3.96 \mu \mathrm{g} / \mathrm{L}$ for groundwater) (Fig. 3). Such elevated contents can be associated with presence of Ni-bearing rocks like amphibolites and serpentinites occurring in Rudawy Janowickie metamorphic unit. The positive correlation between nickel and arsenic as well as nickel and zinc is also observed (Table 2) which may indicate the common origin of these elements.

The chemical composition of groundwater in Czarnów area strictly depends on chemical reactions occurring in water-rock environment. The inverse geochemical modeling with PHREEQC version 3 allowed creating the most probable model of geochemical evolution of groundwater in the study area represented by following chemical processes:

1. Carbon dioxide dissolution,

2. Pyrite oxidation by $\mathrm{O}_{2}$ with iron oxide-hydroxide precipitation,

3. Carbonates dissolution,

4. Plagioclases dissolution with kaolinite precipitation,

5. Ionic exchange between $\mathrm{Ca}^{2+}$ and $\mathrm{Na}^{+}$.
Fig. 3 Selected statistical parameters of trace elements concentrations in waters of the study area

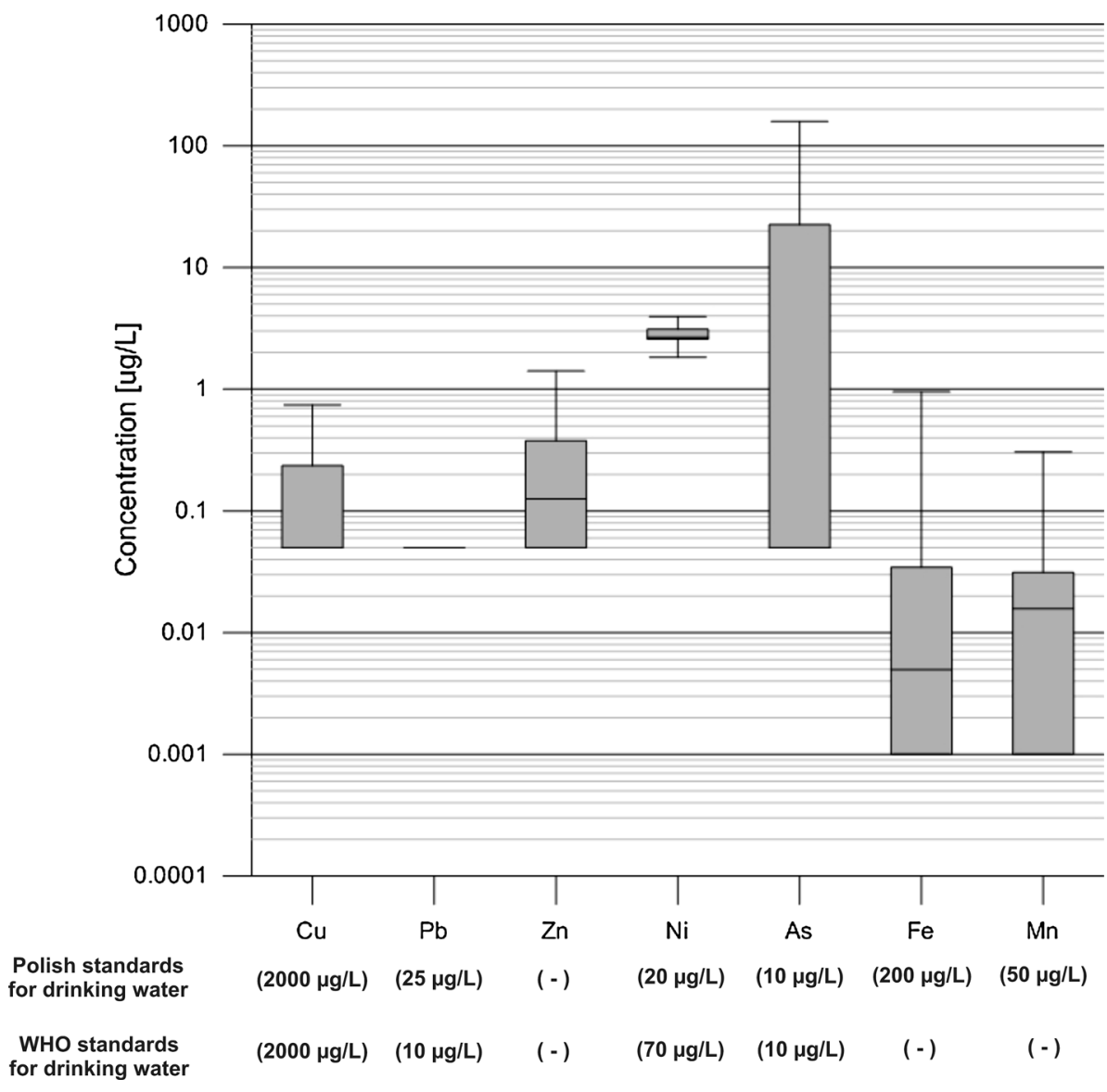




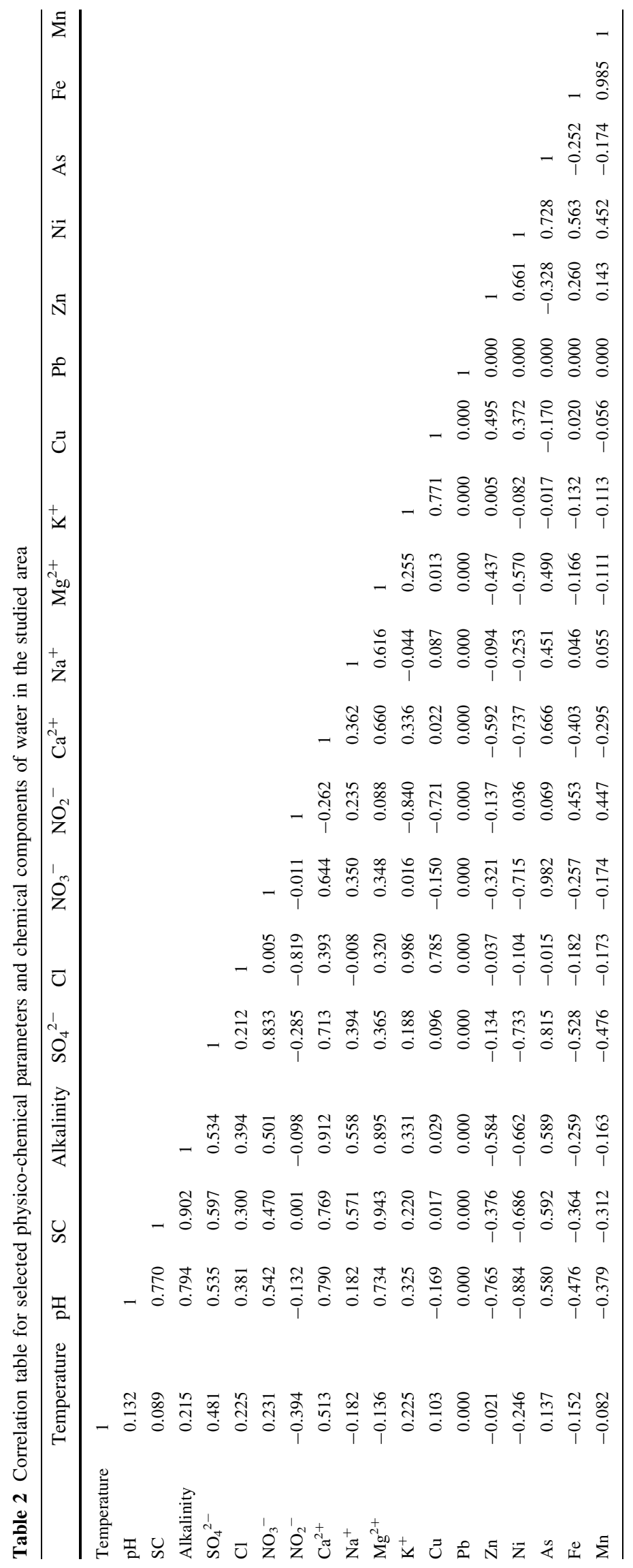


The most significant process is sulfides oxidation reaction occurring in the presence of oxidants such as oxygen and in most cases catalyzed by bacteria activity. The considerable contribution of this process for the total water mineralization can be also visualized as a positive correlation between $\mathrm{SO}_{4}{ }^{2-}$ ions and $\mathrm{EC}$ values (Fig. 4). The basic process of pyrite oxidation runs according to the chemical reaction (Appelo and Postma 2005; Rimstidt and Vaughan 2003):

$\mathrm{FeS}_{2}+15 / 4 \mathrm{O}_{2}+7 / 2 \mathrm{H}_{2} \mathrm{O} \rightarrow \mathrm{Fe}(\mathrm{OH})_{3}+2 \mathrm{SO}_{4}^{2-}+4 \mathrm{H}^{+}$

The effect is release of iron, $\mathrm{SO}_{4}{ }^{2-}$ and $\mathrm{H}^{+}$ions and precipitation of iron oxide-hydroxides in the form of reddish deposit in certain springs and wells. The process explains the low concentration of iron in the solution in most of the sampling sites.

The carbonates present as dolomitic marbles are dissolved by free $\mathrm{H}^{+}$ions. The result of foregoing process is the increase of groundwater alkalinity, hardness and $\mathrm{pH}$. The buffering role of dissolving carbonates favors the precipitation of iron oxide-hydroxides. In the investigation points where the water is oversaturated with calcium and magnesium sulphates the secondary minerals such as gypsum may precipitate. The silicate minerals (plagioclases) are also dissolved with the precipitation of kaolinite.

The arsenic is not present in most of the analyzed water samples due to its probable adsorption on iron oxide-hydroxides. The highest concentrations of arsenic are registered only at the sites of elevated pH of water (Fig. 5). It is unusual situation considering the fact that the alkaline aqueous environment favors adsorption of arsenic from water solution into the structure of iron precipitates. In alkaline waters the decrease of positive charge on the surface of mineral phases can be observed (Dobrzynski and

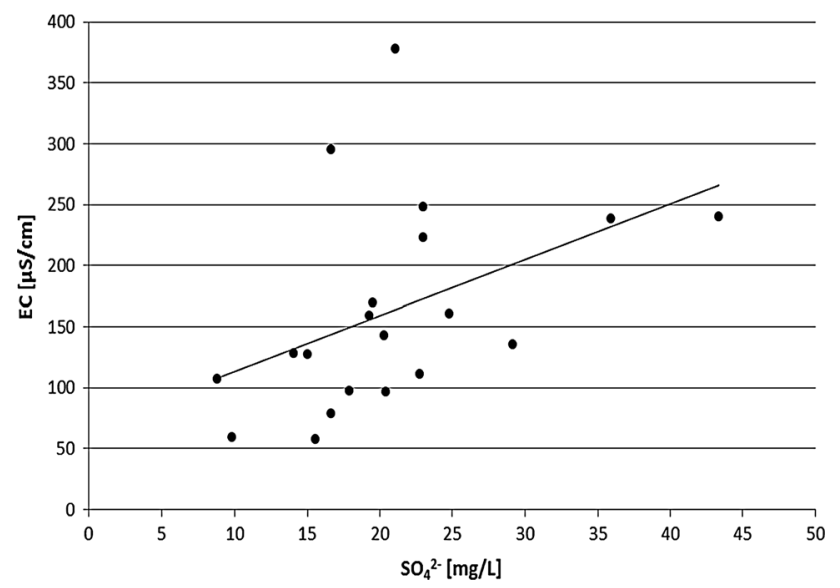

Fig. 4 Concentration of $\mathrm{SO}_{4}{ }^{2-}$ ions versus electrolytic conductivity values (EC) of the studied water samples
Stepien 2009). Results of modeling with PHREEQC version 3 confirmed that the prevalent arsenic species in water solution are $\mathrm{H}_{3} \mathrm{AsO}_{3}$ and $\mathrm{H}_{2} \mathrm{AsO}^{3-} . \mathrm{H}_{3} \mathrm{AsO}_{3}$ species has no electric charge therefore there it has no exchange capacity at all. $\mathrm{H}_{2} \mathrm{AsO}^{3-}$ as an ion with negative charge is not adsorbed on negatively charged surfaces of mineral phases. This situation explains the remaining of high concentrations of arsenic in studies waters. The phenomenon concerns also the other trace elements occurred in the studied water samples (Fig. 6).

The problem of groundwater pollution with arsenic compounds was recognized and commented wildly all over the world, regarding mostly former mining areas characterized by the occurrence of acid mine drainage (AMD) which favours the remaining of arsenic in water solution. The similar unusual phenomenon as observed in Czarnów region concerning the increase of arsenic in groundwater under neutral or alkaline conditions was described in a few areas in the world e.g. Inner Mongolia (Luo et al. 1997; Zhai et al. 1998; Sun et al. 1999), Chaco-Pampean Plain in Argentina (Nicolli et al. 1989, 2001), Arizona in USA (Robertson 1989), Lagunera in Mexico (Del Razo et al. 1990) and Caldes de Malavella in Spain (Piqué et al. 2010).

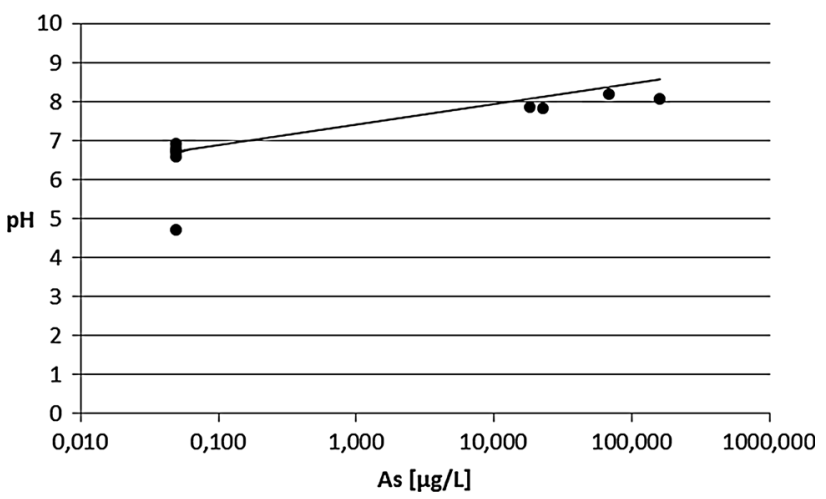

Fig. 5 Concentration of arsenic versus $\mathrm{pH}$ values of the studied water samples

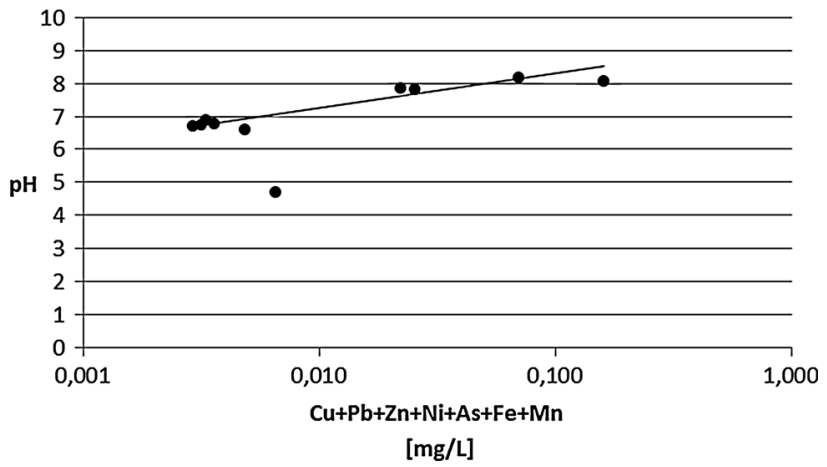

Fig. 6 Total concentration of trace elements versus $\mathrm{pH}$ values in the studied samples 


\section{Conclusion}

The Czarnów area (Rudawy Janowickie Mts., Western Sudetes) is one of the few regions in Poland where the visible impact of long-term mining activity on water environment is observed. The present chemical composition of studied waters is the result of natural geochemical processes occurring within water-rock system intensified strongly by former exploitation of polymetallic deposit and recent exploitation of carbonate rocks. Based on the results of water chemical composition analyses the geochemical model of waters spatial and temporal evolution was created to recognize the most significant chemical reactions controlling water chemistry. The presence of ore (mainly arsenopyrite) mineralization affects the increase of trace metals concentration in the low mineralized waters but neighborhood of carbonate rocks causes alkaline/ neutral mining drainage. The content of As reaching $158.77 \mu \mathrm{g} / \mathrm{L}$ and other metals such as iron, copper, zinc and nickel were detected in waters as well. The elevated concentrations of arsenic, because of its toxic properties, should be a particular health concern for local authorities responsible for water management. Regardless of changes in microelements composition during the past three decades the visible tendency of water enrichment with bicarbonates in relation to sulphates is observed. Even though the chemical processes of sulfides dissolution occurring in groundwater of the study area lead to the increase of trace elements concentration in groundwater, the oxidizing conditions are favorable for waters self-purification and self-protection from degradation.

Open Access This article is distributed under the terms of the Creative Commons Attribution 4.0 International License (http://crea tivecommons.org/licenses/by/4.0/), which permits unrestricted use, distribution, and reproduction in any medium, provided you give appropriate credit to the original author(s) and the source, provide a link to the Creative Commons license, and indicate if changes were made.

\section{References}

Appelo CAJ, Postma D (2005) Geochemistry, groundwater and pollution, 2nd edn. AA Balkema, Rotterdam

Balcerzak E, Dobrzyński D, Parafiniuk J (1992) The effects of mineral alterations on the chemical composition of waters in the weatherd zone of pyrite-bearing schists in Wieściszowice, Rudawy Janowickie Mts., Poland. Ann Soc Geol Polon 62(1):75-93 Kraków (in Polish)

Cymerman Z (1996) Transpression and extension in the Rudawy Janowickie metamorphic complex (Western Sudetes, SW Poland). Prz Geol 44(12):1211-1216 (in Polish)

Del Razo LM, Arellano MA, Cebrian ME (1990) The oxidation states of arsenic in well-water from a chronic arsenicism area of northern Mexico. Environ Pollut 64:143-153

Dobrzyński D, Stępień M (2009) Ocena dystrybucji arsenu w wybranych wodach leczniczych Sudetów na podstawie filtracji membranowej i modelowania specjacyjnego. Biuletyn Państwowego Instytutu Geologicznego 436:95-102 (in Polish)

Dziekoński T (1972) Ore mining and working of nonferrous metals in lower Silesia (Poland) from the 13th to the 20th century. Polish Academy of Sciences, Wrocław (in Polish)

Konieczyńska M (2006) Evaluation of the origin of chemical composition of water from old mine adits in CzarnówMiedzianka-Janowice Wielkie region. Współczesne Problemy Hydrogeologii 13(2):85-93 Wrocław (in Polish)

Kozdrój W (2003) Geotectonic evolution of the East Karkonosze crystalline complex. In: Ciężkowski W et al (eds) Western Sudetes Mts: from Vendian through quaternary. Pol. Tow. Geol., WIND, Wrocław, pp 67-80 (in Polish)

Luo ZD, Zhang YM, Ma L, Zhang GY, He X, Wilson R, Byrd DM, Griffiths JG, Lai S, He L, Grumski K, Lamm SH (1997) Chronic arsenicism and cancer in Inner Mongolia-consequences of well-water arsenic levels greater than $50 \mu \mathrm{g}^{-1}$. In: Abernathy CO, Calderon RL, Chapell WR (eds) Arsenic Exposure and Health Effects. Chapman Hall, London, pp 55-68

Macioszczyk A, Dobrzyński D (2002) Hydrogeochemistry of short turn-over time zone. PWN, Warszawa (in Polish)

Marszałek H (1996) Hydrogeology of the upper part of Kamienna watershed in Western Sudetes. Acta Universitatis Wratislaviensis. No 1881, Vol. 54, The University of Wrocław, Wrocław (in Polish)

Marszałek H, Wąsik M (2001) Hydrogeochemical anomaly in waters of the pyrite deposit area in Wieściszowice (Western Sudetes Mts., SW Poland). In: Seiler KP, Wohnlich S (eds) New approaches characterizing groundwater flow. Swets \& Zeitlinger, Lisse, pp 1031-1034

Mazur S (2003) Eastern envelope of the Karkonosze granite-crosssection of a Variscan suture zone. In: Ciężkowski W et al (eds) Western Sudetes Mts: from Vendian through quaternary. Pol. Tow. Geol. WIND, Wrocław, pp 67-80 (in Polish)

Mazur S, Aleksandrowski P (2001) The Tepla(?)/Saxothuringian suture in the Karkonosze-Izera massif, western Sudetes, central European Variscides. Int J Earth Sci 90:341-360

Mikulski S (2010) The characteristic and genesis of the gold-bearing arsenic polymetallic mineralization in the Czarnów deposit (Western Sudetes). Bull Pol Geol Inst 439:303-320 (in Polish)

Mochnacka K, Oberc-Dziedzic T, Mayer W, Pieczka A, Góralski M (2009) New insights into the mineralization of the Czarnów ore deposit (West Sudetes, Poland). Geol Sud 41:43-56

Nicolli HB, Suriano JM, Peral MAG, Ferpozzi LH, Beleani OA (1989) Groundwater contamination with arsenic and other traceelements in an area of the Pampa, province of Cordoba, Argentina. Environ Geol Water Sci 14:3-16

Nicolli HB, Tineo A, Garcia JW, Falcon CM, Merino MH (2001) Trace-elements quality problems in groundwater from Tucuman, Argentina. In: Cidu R (ed) Water-rock interaction 2001, vol 2. Swets \& Zeitlinger, Lisse, pp 993-996

Piqué A, Grandia F, Canals A (2010) Processes releasing arsenic to groundwater in the Caldes de Malavella geothermal area, NE Spain. Water Res 44(19):5618-5630

Rimstidt JD, Vaughan DJ (2003) Pyrite oxidation: a state-of-the-art assessment of the reaction mechanism. Geochim Cosmochim Acta 67(5):873-880

Robertson FN (1989) Arsenic in groundwater under oxidizing conditions, south-west United States. Environ Geochem Health $11: 171-185$

Staśko S (2010) On groundwater in crystalline rocks of the Sudetes and their foreland. Bull Pol Geol Inst 440:135-144

Sun GF, Dai GJ, Li FJ, Yamauchi H, Yoshida T, Aikawa H (1999) The present situation of chronic arsenism and research in China. In: Abernathy CO, Calderon RL, Chapell WR (eds) Arsenic exposure and health effects. Elsevier, Amsterdam, pp 123-126 
Zagożdżon PP, Madziarz M (eds) (2009) Mining history-element of European culture heritage, vol 2. Ofic. Wyd. P.Wr, Wrocław (in Polish)

Zhai C, Dai G, Zhang Z, Gao H, Li G (1998) An environmental epidemiological study of endemic arsenic poisoning in Inner
Mongolia. In: Abstract 3rd International Conference Arsenic Exposure and Heath Effects, San Diego

Zimnoch E (1985) Ore mineralization of the Czarnów deposit (Sudetes). Ann Soc Geol Polon 53:289-306 Kraków (in Polish) 